Hence the future lies with the farmer, who will have to produce not only the food that we desire but also that which we ought to have in a perfect condition. To do this, the farmer will have to feed his animals properly and this necessitates a great extension in the use of fertilisers on the land. Thus it appears that the "cash chemist" returns to action with a change of function- to supply the farmer with his chemical manures. Prof. Armstrong was despondent at the delay in reaching this condition of a brave new world and concluded with the following words : "at the moment our failure to use intelligence, the world over, is astounding-some fault there must be in developing it. A few months ago in a speech in this city I suggested clearing out the present race of students and their teachers and bringing in 500 chosen boys who could be trained as cooks. I would repeat my advice to-day but add that to cook should mean to understand what is cooked, what is fit and proper to be eaten, as well as the mere art of kitchenry. We cannot get away from the fact that we live always through our stomachs ; from these it is, through the foodwe put into them, that we gain and haveour being."

\section{Electric Welding in Ship Construction}

ELECTRIC welding, instead of rivetting, is being widely adopted in shipbuilding. In German naval dockyards it has practicaliy superseded rivetting. Electrically welded ships have practically no leakage and there is little corrosion or wastage of plates around the welded joints. Economies are effected by welding in the weight and cost of a ship's hull. The welded ship therefore yields greater service for a smaller investment of capital. The University of Glasgow has introduced welding work into its laboratories and the design of welding joints has been introduced into all its engineering courses. The Glasgow Education Committee is also taking steps to form a new skilled class of workmen called ship welders. Before a change of this kind can be made it is necessary for the employers and the trade unions to meet. In the Times of May 26 an account is given of a conference held in Edinburgh between employers' federations and trade unions on this subject. Mr. J. B. Hutchison, the chairman of the employers, stated that it is of the greatest importance that the development of welding should proceed as rapidly and smoothly as possible in Great Britain on economical lines in order that competition with other shipbuilding nations may be suecessfully faced. It is understood that the employers made it clear that the selection of ship welders is likely to be made from the most suitable men, not confined to any one class and not necessarily from men directly displaced by the new process. Mr. Sherwood, on behalf of the unions, said that the proposals were of such a farreaching character that full and careful consideration was necessary.

\section{Electrical Equipment of the Queen of Bermuda}

IN the G.E.C. (General Electric Co.) Journal for May there is a full and interesting description of the electrification of the Furness-Withy liner, Queen of Bermuda. It was launched at Barrow-in-Furness last February and has successfully completed its trials. Its tonnage is 22,500 and its shaft horse power is about 20,000. Electricity is used on the most extensive scale possible throughout the ship. It is used for the propulsion and steering of the ship. It is also used for lighting and ventilation, cooking, refrigeration, the handling of cargo, and there are eleven electric lifts, etc., the auxiliary machinery totalling about 3,000 horse power. For maintaining a supply of power adequate for essential services in cases of emergency, an oil-engine-driven dynamo of 50 kilowatts capacity is installed on one of the upper decks well above the water line. The change over of the panic-lighting circuits from the emergency busbars to a battery is entirely automatic and takes place on the failure of the supply voltage. The vessel is intended primarily for service between New York and Bermuda but she has been constructed for ocean-cruising as well. In view of the large amount of perishable foodstuffs which have to be carried, extensive refrigerating plant is provided. For this purpose, 23 motors are required, the largest being of 70 horse power for driving a carbon dioxide compressor. The lighting is done on a very lavish scale, requiring 450 kilowatts of electric energy. It is mainly effected by concealed lighting in opaque cornices, diffused lighting through continuous glazed cornices, or box lights glazed with tinted diffusing glasses in modern designs. For illuminating the dancing space three-colour lighting is used for the main ceiling. The lights are controlled by dimmers when dancing is in progress so as to produce a pleasing variation in the colour of the illumination. This is a great improvement on jazz' lighting.

\section{Freshwater Biological Association}

The annual general meeting of the Freshwater Biological Association of the British Empire was held on May 11 in the rooms of the British Waterworks Association, Grand Buildings, Trafalgar Square, W.C.2. The following officers were elected for 1933-34 :--President, Mr. Reginald Beddington; Chairman of Council, Prof. F. E. Fritsch; Hon. Treasurer, Mr. Nigel O. Walker; Hon. Director of the Laboratory, Dr. W. H. Pearsall ; Hon. Secretary, Mr. J. T. Saunders. The report of the Council showed that considerable progress has been made in fitting out the Laboratory of the Association at Wray Castle at Windermere. Tables are now available for visiting research workers and accommodation for these workers is provided in the Castle. Subscriptions have been received from a wide circle interested in freshwater problems. Subscriptions, renting tables at the Laboratory, have also been received from universities, many of which have already nominated research workers to occupy their tables at the Laboratory. The Council is anxious to provide the fullest possible facilities at the Laboratory for those who wish to work on freshwater problems. The most pressing need at the moment is the provision of an electric supply for the Laboratory, but the Council has at present no funds to supply this need. The address of the honorary secretary of the Association is Mr. J. T. Saunders, Christ's College, Cambridge. 